\title{
PERCEPÇÕES DE MUNDO
}

As expressões de cultura e arte populares se constituem em campo de amplo interesse que se consolidou no Brasil há muitas décadas. Foi na virada do século 19 para o 20 que o crítico e historiador de literatura Silvio Romero (1851-1914) chamou a atenção nacional para a poesia popular, legitimando esse universo junto aos estudos de literatura no país.

De lá para cá, muita água tem passado sob a ponte. O universo se ampliou, as descrições, de início marcadas pelo empirismo, foram paulatinamente se transformando em análises da realidade social, teoricamente fundamentadas, e o campo foi reconhecido como de interesse científico pelas ciências humanas e sociais cuja formação se deu por volta dos anos 30 do século passado.

Vivemos agora no século 21, novo milênio cujos primeiros anos têm sido definidos por rompimento de fronteiras, desconstruções, globalizações, hibridizações, ressignificações, (des)territorializações. .. Percepções de mundo que põem ênfase no fazer ao inverso, no prefixo negativo que passa a presidir praticamente toda ação e reflexão do homem e da realidade social.

A revista TEXTOS ESCOLHIDOS DE CULTURA E ARTE POPULARES, como parte deste universo, acompanha as transformações presentes também no campo dos estudos do popular. Neste número são apresentados 14 artigos que refletem o modo como as culturas populares são vistas e vividas no momento presente, no Brasil e no exterior.

As temáticas abordadas são também testemunho deste campo ampliado. Os artigos refletem e retratam realidades como rituais do catolicismo popular, representações sociais, festa, teatro, performance, dança, culinária afro-brasileira, pintura ex-votiva, arquitetura, arte, educação patrimonial, religião, literatura, cantoria e música, colocando em interação o erudito, o midiático e o popular.

\section{Ricardo Gomes Lima [coeditor]}

